\title{
KIKŌ - ZAPISKI Z SAMOTNEJ PODRÓŻY
}

O szerokim zakresie odcieni samotności i bogactwie sposobów jej odczuwania w japońskiej sferze językowo-kulturowej świadczy wielowymiarowość związanego z tym pojęciem słownictwa. Prototypowe wyobrażenie samotności oddają słowa kodoku i sabishi. Kodoku to wszelkie formy odosobnienia i wyobcowania. Składa się z dwóch znaków: ko (sam, osamotniony, osierocony, bezdomny; jedna z najbardziej dotkliwych postaci samotności w sino-japońskim kręgu kulturowym) i doku (jeden, jedyny, samotny, obcy). Angielskim odpowiednikiem kodoku jest loneliness, alienation, a francuskim solitude.

Sabishi lub urasabishi ${ }^{1}$, starsze, a jednocześnie poszerzające krąg znaczeniowy, oprócz "samotności" oznacza smutek, tęsknotę, pragnienie ${ }^{2}$. Sabishi opisuje odczucie braku ludzi i przedmiotów/sytuacji, które przynoszą radość. Wyraz ten zapisywany jest logograficznie na dwa sposoby: pierwszy element oddaje subiektywne, indywidualne poczucie samotności i żalu, a drugi obiektywne, obserwowalne odczucie bycia oddalonym, porzuconym, zapomnianym (dotyczy to zwłaszcza miejsc i przedmiotów). Inny przykład to słowo shū (czytane niekiedy urē), które znaczy „smutek, tęsknotę, melancholię wynikającą z poczucia odosobnienia".

Współcześnie powszechnie stosowane jest również słowo hitori, które w zależności od kontekstu oznaczać może "jednego człowieka” (a więc po prostu liczbę) lub człowieka samotnego. Od słowa hitori, zapisywanego zna-

${ }^{1}$ Ura jest innym odczytem znaku kokoro oznaczającego serce, duszę.

2 Opracowano na podstawie Zenyaku kogo jiten (Słownik klasycznego japońskiego wraz z tłumaczeniami [na współczesny japoński]), oprac. Miyakoshi Sakurai, Tokyo 1999. 
kami jako "jeden” i "człowiek”, powstały takie zwroty, jak hitori asobi (samotna zabawa), hitori gurashi (mieszkać samotnie), hitori $i$ (być samemu), hitori tabi (samotna podróż $)^{3}$.

Jak widać na powyższych przykładach, już choćby krótka analiza semantyczna oraz zebranie informacji o charakterze leksykograficzno-etymologicznym pozwoliłyby na wydzielenie kilku leksemów-kluczy, które mogłyby posłużyć do odkodowania sposobu i zakresu wyrażania „samotności” w języku japońskim ${ }^{4}$.

Ponadto, warto również zwrócić uwagę na obecność w języku japońskim słów i wyrażeń, które, choć bezpośrednio nie oznaczają "samotności”, służą do wyrażenia odczucia wyobcowania na linii "ja”, ,"moje” (uchi), i to, co obce, inne, odległe (soto). Perspektywa patrzenia na siebie i na obcego, a także poszukiwania swojego miejsca $w$ świecie obcego, obecna jest i rozwijana szczególnie w motywie podróży, zwłaszcza podróży samotnej. Dlatego mówiąc o samotności w kontekście kultury japońskiej, można spojrzeć na to zagadnienie $\mathrm{w}$ zestawieniu $\mathrm{z}$ tym motywem, gdyż dostarcza on znacznie bogatszej leksyki do zobrazowania problemu samotności. Pokonywany w trakcie podróży dystans nie tylko intensyfikuje odczucie samotności, ale też wyostrza optykę spojrzenia na uchi-soto (ja/moje - obce), czego ciekawym przykładem są słowa ihōjin (obcy, inny, samotny), monokoishi (oznaczające samotność wywołaną tęsknotą za domem i bliskimi) czy ryoshū (które przetłumaczyć można jako „smutek, melancholię, poczucie odosobnienia” doświadczane podczas podróży i pobytu w obcym miejscu).

Prezentowany tutaj artykuł stanowi próbę przyjrzenia się „obrazom” samotności utrwalonym w szczególnej formie narracyjnej zwanej $k i k \bar{o}^{5}$ (dosł. zapiski/dziennik z podróży). Ponieważ nie jest moim celem dokonywanie szczegółowej analizy tego gatunku, dlatego też jedynie $\mathrm{w}$ formie informacyjnej, dalece uproszczonej, pokażę, na czym polega specyfika i swoista trwałość kikō na gruncie tradycji literackiej Japonii, by następnie zaprezentować współczesny przykład „zapisków z podróży”, których autorem jest

${ }^{3}$ Ciekawym słowem, dziś używanym nieco idiomatycznie, jest inton (życie w samotności, z dala od świata). Dosłownie oznacza ono "ucieczkę w cień, ciemność", „odrzucenie świata”, i wyraźnie nawiązuje do buddyjskiej koncepcji życia pustelniczego.

${ }^{4}$ Do podanych wyżej przykładów można dodać specyficzne dla japońskiego wyrazy mimetyczne (ideofony/psychomimy), które oddają rozmaite oblicza samotności, takie jak: shonbori (samotny i odrzucony); hissori (samotny i cichy); shinmiri (samotny i pełen smutku, wzruszenia); garanto (samotny, opuszczony, pusty; dotyczy miejsc, które wywołują takie odczucia).

${ }^{5}$ Donald Keene tłumaczy kikō jako "travel-diary” lub "travel record”. W artykule stosuję nazwę zbliżoną do angielskiego tłumaczenia. Zob. D. Keene, Appreciations of Japanese Culture, Tokyo 2002. 
pisarz Endō Shūsaku (1923-1996) ${ }^{6}$. Jego esej zatytułowany Terēzu no kage o otte („W pogoni za cieniem Teresy”, 1952 r.) jest relacją z podróży autora do miejsc związanych z bohaterką powieści François Mauriaca Teresa Desqueyroux. Problem samotności zostaje więc ujęty w kontekście samotnej podróży literackiej, gdzie rzeczywistość świata realnego nieustanne przeplata się ze światem powieściowym.

Japońskie świadectwa literackie opisujące podróże szlakiem wyznaczonym przez bohaterów literackich (także do miejsc opisanych w literaturze czy związanych z osobą autora), kładą nacisk nie tylko na opisy topograficzne czy chronologię wydarzeń, ale właśnie na problem samotności, która dotyka podróżującego autora. Od IX wieku (czyli od tak zwanej epoki Heian 794-1185) popularyzacja literatury diarystycznej sprzyjała podejmowaniu samotnych podróży i tym samym rozwijaniu kolejnych form literackich, w tym podgatunku kikō. Początki kikō wiążą się również z działalnością tzw. tabito (dosłownie: „poetów podróżujących”). Nie tylko wędrują oni wytyczonym przez literaturę szlakiem, ale sami podczas podróży komponują poezję czy prowadzą pogłębioną refleksję nad własnym warsztatem twórczym. Samotnej podróży tabito poświęcona została najstarsza forma poetycka - waka, a więc pieśń japońska. W jednej z nich, zamieszczonej w pierwszej antologii poezji Man'yōshū („Zbiór dziesięciu tysięcy liści”, ok. 790 r.), czytamy: "Czy jest coś co może naprawić ból, który towarzyszy samotnej podróży?"7.

Przykładem samotnej podróży literackiej jest Dziennik z Sarashiry (10591062) autorstwa anonimowej autorki, o której wiadomo jedynie, że wędruje do Kyoto (ówczesnej stolicy Japonii), a podczas swojej podróży nieustannie odwołuje się do postaci i wątków znanych z powieści Genji monogatari („Opowieść o księciu Promienistym”, 1010 r.) autorstwa Murasaki Shikibu (978-1016). Krytycy japońscy, próbując ustalić tożsamość autorki dziennika, określali ją mianem "młodej kobiety, która pragnie udać się w podróż do stolicy, by tam móc czytać wszystkie dzieła literackie" ${ }^{8}$. Celem podróży jest więc stolica, centrum kulturalne, które dostarczyć ma jej dzieł literackich

${ }^{6} \mathrm{Na}$ temat życia i twórczości Endō Shūsaku zob. mój artykuł Przyjmując chrzest każdego dnia. Endō Shūsaku wobec dylematów pisarza nawróconego, "Zeszyty Naukowe Centrum Badań im. Edyty Stein” 2009, nr 5: „Wielcy mistycy - wielkie przemiany”, red. A. Grzegorczyk, M. Kościańczuk, s. 179-190.

${ }^{7}$ Fragment pochodzi z Zenyaku kogo jiten, op. cit. Jeśli nie zaznaczono inaczej, tłumaczenie Autorki.

8 O próbach interpretacji Dziennika z Sarashiny w Japonii pisze Edith Sarra w rozdziale Fictions of Desire in the "Sarashina nikki", [w:] eadem, Fictions of Femininity: Literary Inventions of Gender in Japanese Court Women's Memoirs, Stanford 1999, s. 81-83. 
(a wylicza je ona bardzo skrupulatnie w swoim dzienniku), by móc czytać nie tylko ,jedno za drugim, od rana do nocy, ale przede wszystkim w samotności" ${ }^{9}$. Podczas swojej podróży autorka przede wszystkim udziela głosu bohaterom powieści. Wszelkie stany emocjonalne, takie jak smutek, ból, trudy podróży, samotność, wyrażane są językiem dzieła Murasaki Shikibu do tego stopnia, że mamy do czynienia $\mathrm{z}$ wewnętrznym dialogiem prowadzonym między autorką dziennika a autorką powieści ${ }^{10}$.

Klasycznym już przykładem samotnej podróży do miejsc związanych z literaturą japońską jest dziennik Matsuo Bashō (1644-1694) Oku no hosomichi („Ścieżkami północy”, 1689 r.). Podczas swojej podróży Bashō kieruje się szlakiem średniowiecznego poety Saigyō (1118-1190). Odwiedza miejsca związane z jego osobą, ale również utrwalone w jego poezji. Podczas podróży, Bashō nie tylko przywołuje postać średniowiecznego poety, ale też komponuje własne utwory (haiku). Jak podkreśla Donald Keene, czytając dziennik Bashō, mamy wrażenie, jakby głównym motywem podróży była próba ulepszenia własnego warsztatu twórczego poprzez kontakt z miejscami związanymi z osobą innego poety. Dlatego dziennik Bashō określany jest nie tylko jako kikō, ale też jako uta nikki - dziennik poetycki, w którym narracja typowa dla japońskiej literatury diarystycznej (szczególnie opisy topograficzne) zostaje uzupełniona fragmentami poezji11.

Samotne podróże literackie stały się ważnym elementem w kontaktach pisarzy japońskich ze światem zachodnim począwszy od połowy XIX stulecia, a więc od czasu tak zwanego „otwarcia Japonii”, czyli wejścia na drogę modernizacji i wielowymiarowej westernizacji (w życiu politycznym, społecznym i kulturalnym). Gwałtowne zmiany, które dotknęły Japonię i Japończyków na przełomie epok Meiji i Taishō, nie obyły się bez pewnych konsekwencji. Jak zauważa Rachel Hutchinson:

Wileki niepokój wzbudzała kwestia, jak wkroczyć w świat współczesny bez poświęcania tożsamości japońskiej. Politycy, dziennikarze i pisarze wszyscy prowadzili dyskusje na temat dylematów wspótczesności ${ }^{12}$.

Owe dylematy wspótczesności - pośród których najistotniejszym okazała się kwestia tożsamości narodowej - stały się przewodnim tematem ówcze-

\footnotetext{
${ }^{9}$ Cyt. za: ibidem, s. 108.

10 Jak zauważa Edith Sarra, japońscy krytycy podkreślają również walory krytyczno-literackie Dziennika z Sarashiny - pogłębioną refleksję nad istotą fikcji literackiej i obraz recepcji dzieła Murasaki Shikibu wśród czytelników (głównie czytelniczek) epoki Heian (ibidem, s. 82-91).

${ }^{11}$ D. Keene, The Japanese as Revealed: Travelers of a Hundred Ages. Through 1000 Years of Diaries, New York 1995, s. 310-311.

12 R. Hutchinson, Nagai Kafü's Occidentalism: Defining the Japanese Self, Albany 2011, s. 1.
} 
snej literatury zarówno beletrystycznej, jak i diarystycznej czy autobiograficznej. Kontynuując tradycję średniowiecznych tabito, pisarze końca XIX i początku XX stulecia wyruszali w samotne podróże, by tam - w rzeczywistych warunkach - móc lepiej przyswoić treści kultury i literatury europejskiej. Przykładem jest obszerny tekst - pisany we fragmentach w formie dziennika - pisarza Nagai Kafū (1879-1959) pod tytułem Opowieści francuskie $(1909 \text { r. })^{13}$. W swoim dzienniku z podróży do Francji, Kafū, tłumacz i krytyk literatury francuskiej, zastanawia się (kierując swoje słowa bezpośrednio do Maupassanta, którego nazywa sensei, czyli mistrzem), na ile podróż pozwoli mu opanować warsztat pisarski na miarę francuskiego pisarza. Kafū nie ukrywa swojej determinacji, gdy pisze

Za wszelką cenę pragnąłem przyjechać do Francji by na własne oczy móc zobaczyć świat, który ty, mistrzu, opisałeś [w swoich powieściach - przyp. J.W.K.]. Gdy uświadomiłem sobie moją własną ambicję, wówczas podjąłem decyzję, by nigdy nie wracać do Japonii...14

We fragmentach, które stanowią przykład kontynuacji tradycji kikō, na pierwszy plan wysuwa się dość szczególnie przez Kafū wyrażana samotność, dająca się ująć w kategoriach uchi (moje) i soto (obce) jako próba odnalezienia miejsca w "nieswoim świecie”, w "świecie nieswojej literatury”. Niemal cały ten zbiór to świadectwo, zapis - niekiedy jako dziennik, czasem jako opowiadanie, a innym razem jako chaotyczna i niespójna notatka zmagań autora z samotnością, zarówno tą emocjonalną, jak i twórczą, którą wywołuje niemoc wejścia w kulturę europejską, ale jednocześnie nieustannie towarzysząca mu niechęć powrotu do rodzinnego kraju.

Powyższe omówienie motywu samotnej podróży literackiej na przykładzie dzienników z trzech różnych epok - choć nie wyczerpuje ogromu innych zagadnień, które należałoby przy okazji tego tematu poruszyć - pozwala jednak skierować uwagę na zasadnicze wątki artykułu: pierwszy to charakterystyka samego gatunku literackiego kikō na tle głównych zjawisk tak zwanej "literatury o sobie” w piśmiennictwie japońskim, drugi zaś to obraz samotności, jaki wyłania się z eseju/dziennika Endō Shūsaku.

Próbując dokonać pewnej ogólnej syntezy, nie będzie przesadą powiedzenie, że dla autorów, narratorów i bohaterów dzienników, w tym także Endō, podróż jest tym, co w języku angielskim określa słowo quest, czyli

${ }^{13}$ D. Keene, Diaries of Nagai Kafü, [w:] idem, Modern Japanese Diaries: The Japanese at Home and Abroad as Revealed through Their Diaries, New York 1999, s. 488-505.

14 Tłumaczenie z języka angielskiego na podstawie: D. Keene, Dawn to the West. Japanese Literature in the Modern Era, ("A History of Japanese Literature”, vol. 3), New York 1998, s. 410. 
wyprawa (rozumiana jako pewna forma poszukiwania). Jeśliby spróbować kierować się rozróżnieniami zaproponowanymi przez Josepha Campbella, który określa poszczególne fazy wyprawy archetypowego bohatera jako "odejście”, „inicjacja” i „powrót”15, zobaczymy, jak podobnie przebiega to w przypadku podróży opisanych w japońskich kikō. Campbellowski model podróży pokazuje drogę formowania się bohatera, jego kośćca moralnego i psychicznego, w obliczu przeciwności, które niesie ze sobą podróż. Dla omówionych autorów kikō podróż jest drogą formowania tożsamości czytelniczej (anonimowa autorka Dziennika z Sarashiny), tożsamości pisarskiej (Matsuo Bashō, Kafū) czy poniekąd tożsamości narodowej (przypadek Kafū).

\section{Kikō i japońska tradycja narracji o sobie}

Kikō pisane są zazwyczaj w formie dziennika, w rzeczywistości jednak stanowią literacki kolaż, w którym oprócz opisów przebiegu wyprawy (miejsc, napotkanych ludzi, krajobrazu), autor zamieszcza fragmenty swoich utworów lub tych, które czyta podczas podróży. Kikō to również świadectwo „literackiej pielgrzymki” szlakiem miejsc związanych z literaturą, jej bohaterami, ale też i z miejscami o charakterze religijnym.

Kikō należy do bogatej tradycji „narracji o sobie”, w której mieszczą się rozmaite odmiany pisarstwa autobiograficznego: pamiętniki, nikki (dziennik), zuihitsu (eseje, szkice), czy wreszcie współczesna odmiana powieści zwana shishōsetsu (powieść o sobie ${ }^{16}$ ). Encyklopedia języka japońskiego (Kokugo jiten) definiuje kikō jako zapis doświadczeń, obserwacji i wrażeń autora (lub autorów) z podróży, i podaje, że istnieje wiele form kikō - od prostych opisów topograficznych po teksty wyróżniające się głęboką refleksją autora, w których szczególną uwagę kładzie się na walory stylistyczne tekstu17.

Jednakże, jak zauważa japoński krytyk Haruo Shirane, definicja tego gatunku literackiego wychodzi poza ramy wyznaczone przez teoretyków literatury diarystcznej na Zachodzie, na przykład Philippe'a Lejeune'e (journal intime), przede wszystkim poprzez sposoby traktowania czasoprzestrzeni i osoby autora/narratora. Lejeune definiuje dziennik jako „pamięć życia psychicznego", uznając go za formę, która "opowiada o życiu bez zakłóceń,

\footnotetext{
${ }^{15}$ Opracowano na podstawie: J. Campbell, The Hero with a Thousand Faces, Princeton 1968.

${ }_{16}$ Nihon bungaku-shi („Historia literatury japońskiej”), red. Yamagishi Tokuhei, Tokyo 1997, s. 63-64.

17 E.R. Miner, Japanese Poetic Diaries, Berkeley 1969, s. 14
} 
bez zmian”, i w przeciwieństwie do autobiografii - stanowi „projekt chwilowy, opowieść, której zasadniczą cechą jest spontaniczność”18.

Tak jak inne formy wpisujące się w krąg „narracji o sobie” (czy nikki bungaku -literatury diarystycznej), kikō, choć treścią nawiązuje do wątków z życia autora, nie wyklucza również elementów fikcji literackiej, zapisów historiograficznych czy włączenia fragmentów poezji i prozy będących niekoniecznie dziełem autora kikō. Dlatego często mówi się o „literackim dzienniku”, „dzienniku zbeletryzowanym” czy „poetyckim dzienniku”19, w którym autor czyni siebie bohaterem - postacią fikcyjną. Obecność wątków wychodzących poza życie osobiste autora przywodzi na myśl zaproponowany przez George'a Gusdorfa podział na "dzienniki ekstrawertyczne”, w których autor przyjmuje postawę świadka, obserwatora, a świat opisywany jest przez pryzmat własnych doświadczeń, i tak zwane „introwertyczne," gdzie świat obserwowany i opisywany staje się źródłem przeżyć wewnętrznych. W japońskich dziennikach z podróży, szczególnie tych pisanych współcześnie, te dwie płaszczyzny nieustannie przeplatają się nawzajem.

Kwestią sporną - z perspektywy europejskich badań nad dziennikiem która również wymaga wyjaśnienia, pozostaje związek między podróżą a czasem powstania utworu. Trudno tu mówić o symultaniczności czy zgodności czasowej. Kikō mogą być pisane z odległej perspektywy czasowej i tym samym, jak sugeruje Shirane, porównać je należy do takiej formy literackiej, jaką są mémoires, czyli „wspomnienia”, a więc to, co w Japonii określane jest jako jishō bungaku (literatura retrospekcyjna). Chodzi tu więc nie $\mathrm{o}$ „uwiecznienie chwili” przez diarystę, ale o nadanie jej formy finalnej, ostatecznego kształtu, znaczenia - co niejednokrotnie dokonuje się znacznie później.

W przeciwieństwie do journal intime (w rozumieniu Lejeune'a), wyraźnie na plan pierwszy wysuwa się literackość dzieła, bowiem kikō, w odróżnieniu od dzienników powstających w tradycji europejskiej - jak podkreśla Lejeune: „niemających ambicji literackości [...], pozbawionych zbędnych ograniczeń formalnych" 20 - mimo zawartego w sobie ładunku emocjonalnego i intymnego nie wykluczają obecności konkretnego adresata, a więc czytelnika. Kikō nie są jedynie wspomnieniem, konfesją, ale dziełem intertekstualnym, dosłownie uzupełnionym innymi formami literackimi, a to $\mathrm{z}$ kolei

18 Entretien Philippe Lejeune, „Books: livres et idées du mondes entier” 2013, nr 45: „Étonnants journaux intimes", s. 14-15.

${ }^{19}$ E.R. Miner, op. cit., s. 14.

${ }^{20}$ Entretien Philippe Lejeune, op. cit., s. 15. 
sprawia, że nie są to nigdy utwory monotematyczne, skupiające się na jednym, często wąskim fragmencie doświadczenia ${ }^{21}$.

\section{Samotna podróż Endō Shūsaku W pogoni za cieniem Teresy}

Esej W pogoni za cieniem Teresy, wydany w roku 1952, jest zapisem podróży, którą początkujący pisarz odbył do miejsc związanych z twórczością François Mauriaca. Jak wskazuje sam tytuł, Endō przemierza szlak wyznaczony przez jedną z bohaterek powieści Mauriaca - Teresę Desqueyroux.

Fragmenty eseju pierwotnie znalazły się $\mathrm{w}$ dzienniku prowadzonym przez Endō podczas pobytu na stypendium we Francji w latach 1950-1953, a sama podróż miała miejsce w sierpniu 1951 roku. W dzienniku tym Endō nadał fragmentom opisującym pobyt $\mathrm{w}$ południowo-zachodniej Francji, czyli Landes, wspólny tytuł: Dziennik z badań nad Mauriaciem. To właśnie one złożyły się na esej $W$ pogoni za cieniem Teresy.

Jeszcze przed wyjazdem do Francji Endō żywo interesował się twórczością François Mauriaca. Postrzegał go jako wiodąca postać w kręgu francuskich pisarzy katolickich. W odniesieniu do jego twórczości formułował dylematy, przed którymi staje pisarz katolicki - zarówno twórcze, jak i warsztatowe oraz moralne. Jego uwaga koncentrowała się między innymi na konieczności podejmowania przez tych pisarzy takich tematów, jak problemu zła, grzechu czy zbawienia bohatera. O tym, że są to istotne dla niego problemy, świadczy fakt, że analizował je już w pierwszym swoim eseju pisanym jeszcze $\mathrm{w}$ czasie studiów ${ }^{22}$.

${ }^{21}$ Regina Lubas-Bartoszyńska w swojej pracy Pisanie autobiograficzne w kontekstach europejskich zauważa, że „monotematyczność” stanowi częsty element dzienników europejskich; zob. R. Lubas-Bartoszyńska, Pisanie autobiograficzne w kontekstach europejskich, Katowice 2003, s. 41.

${ }^{22}$ Mowa o eseju Katorikku sakka no mondai („Dylematy pisarzy katolickich”) z roku 1947. Pisarstwem Mauriaca zainteresowana była też inna japońska pisarka katolicka, Takahashi Takako (1932-2013), która również tłumaczyła jego dzieła. François Mauriac był pisarzem wzbudzającym wyjątkowo duże zainteresowanie w Japonii, dlatego wiele znaczących postaci literatury japońskiej wyraźnie pozostawało pod wpływem jego twórczości. Zainteresowanie to nie ograniczało się jedynie do środowisk związanych z nurtem literatury i myśli katolickiej. Dwie najważniejsze powieści Hori Tatsuo (1904-1953), jednego z czołowych pisarzy japońskiego modernizmu, powstały pod silnym wpływem twórczości Mauriaca: powieść Naoko (1941 r.) to japońska wersja Teresy Desqueyroux, natomiast Arano („Ziemia jałowa”, 1941 r.) nawiązuje do Pustyni miłości. Hori był też autorem pierwszych tekstów krytycznych w języku japońskim na temat Mauriaca, w których analizował jego technikę pisarską. $W$ okresie wojennym i powojennym, zainteresowanie twórczością Mauriaca kontynuuje środowisko pisarzy i intelektualistów związanych z grupą Matinée Poetique, w tym najważniejsze jej postacie: Nakamura 
W eseju W pogoni za cieniem Teresy, Endō - student literatury francuskiej, będący zaledwie u progu swojej kariery literackiej - staje się badaczem i podróżnikiem, który jednocześnie podejmuje się szczególnego sposobu (od)czytania powieści - Teresy Desqueyroux - którą pod koniec życia nazwie „powieścią, którą ukochałem”.

Czytając zapis podróży Endō do „krainy mauriakowskiej”, musimy mieć na uwadze, że nieustannie przeplatają się w tekście dwa światy: świat rzeczywisty, realny, a więc rzetelny opis miejsc, ludzi, krajobrazu zastanego przez japońskiego podróżnika, oraz świat literacki, wyimaginowany, odtworzony przez Endō - czytelnika prozy Mauriaca. Wyprawa, którą podejmuje Endō, to próba skonfrontowania świata fikcji literackiej (świata opisanego przez Mauriaca) z „rzeczywistością".

Podróż Endō w okolice Bordeaux (Mauriakowskich Landes) jest podróżą samotną. Nie należy tego rozumieć tylko w sensie dosłownym - jest to również "samotność" wynikająca z faktu bycia samotnym czytelnikiem Mauriaca w warunkach powojennej Francji. Endō pisze o tym już na samym początku swojego eseju, kiedy uświadamia sobie, że jego francuscy rówieśnicy nie czytają powieści Mauriaca z takim samym jak on zaangażowaniem.

Jak bardzo kochałem czytać Mauriaca w Japonii [...], ale moja lektura Mauriaca stopniowo uległa zmianie. Odkąd przybyłem do Francji, widzę jego dzieła w zupełnie innym świetle ${ }^{23}$.

Shin'ichirō (1918-1997) i Fukunaga Takehiko (1918-1979). Grupa Matinée Poetique, do której należeli również nauczyciele i wykładowcy Endō z Uniwersytetu Keio, zajmowała się interpretacją zjawisk charakterystycznych dla klasycznej literatury japońskiej z perspektywy współczesnej literatury europejskiej. Oprócz twórczości Mauriaca, interesował ich też Gide czy Proust; (zob. Nishikawa Nagao, France in Japan: An Essay on the Matinée Poetique Group, [w:] Confluences: Postwar Japan and France, red. D. Slaymaker, Ann Arbor 2002 s. 69-85). Ciekawym przykładem recepcji Mauriaca jest twórczość Yukio Mishimy (1925-1970), którego powieść Ai no kawaki („Pragnienie miłości”, 1950 r.) wyraźnie nawiązuje do treści Teresy Desqueyroux. Według Mishimy, „nie ma drugiego takiego pisarza, który odpowiadały japońskim gustom, jak Mauriac"; (D. Keene, Appreciations of Japanese Cultures, op. cit., s. 210.) Tłumacz i krytyk literatury francuskiej, Katō Shūichi, podsumował oddziaływanie Mauriaca na pisarzy japońskich w następujący sposób: „Mauriac to ważna postać dla japońskich pisarzy powojennych. Pisze niedługie dzieła, tak naprawdę récits, w których opowiada historię zamkniętych rodzin, krewnych, znajomych, żyjących w tym samym domu pośród sosnowych lasów Landes, najbardziej oddalonego rejonu Francji, znanego z pojedynczych, samotnych domów i małych miasteczek. W tych zamkniętych grupach, mężczyźni i kobiety, bracia i siostry walczą o przetrwanie [...]. To właśnie wymiar psychologiczny postaci najbardziej przyciąga pisarzy japońskich [...]. Hori Tatsuo jako pierwszy zwrócił na to uwagę. Mogę powiedzieć, że do pewnego stopnia, pisarstwo Mauriaca przypomina japońską powieść o «sobie» (shishōsetsu), a więc naszą tradycyjną powieść konfesyjną." (Katō Shūichi, Thinking Beyond Parallel Traditions: Literature and Thought in Postwar Japan and France, [w:] Confluences: Postwar Japan and France, op. cit., s. 60).

${ }^{23}$ Endō Shūsaku, Terēzu no kage o otte, [w:] Endō Shūsaku Bungaku Zenshū („Zbiór wszystkich dzieł Endō Shūsaku"), tom 12 Tokyo, 2004, s. 143-144. Dalsze cytaty z tej pozycji lokalizuję bezpośrednio w tekście, podając numer strony. 
Być może dlatego notuje w swym dzienniku: „Poprzez tę podróż chciałem usilnie sprawić, by zniknął obraz Teresy, który był do tej pory we mnie" (s. 151). Ale co wydaje się bardzo charakterystyczne, przygotowując się do podróży, zdradza, iż:

w rezultacie desperacko zacząłem interesować się samotnym życiem Teresy, [...] która nie była w stanie uciec od samotności i przeznaczenia. Dlatego rozpocząłem tę podróż tak daleką w dziką pustkę, gdzie spędziła swoje bolesne życie (s. 150).

Esej ten prowadzony jest $\mathrm{w}$ taki sposób iż możemy powiedzieć, że daje obraz rejestrowanemu przez pisarza wielopostaciowemu i bardzo dynamicznemu doświadczeniu samotności24. Dynamika ta budowana jest wraz z rozwijającą się podróżą, z pokonywaniem zasadniczych jej etapów. Dokonuje się to $\mathrm{w}$ dwojaki sposób. $\mathrm{Z}$ jednej strony autor sporządza bardzo szczegółowy opis topograficzny miejsca akcji powieści Mauriaca, z którego dowiadujemy się, gdzie dokładnie leży powieściowe Argelouse i co charakteryzuje to miejsce: "odcięte jest [ono] od świata bagnistą ziemią nie do przebycia, niekończącym się ciemnym i ponurym lasem sosnowym, [jest to] ziemia paproci i roślin ciernistych [...] zapomniana i odseparowana część świata" (s. 153). Z drugiej zaś, uruchamia całą serię pytań na temat motywów postępowania mauriakowskiej bohaterki. Powieściowy wątek otrucia męża przez Teresę zostaje poddany analizie w sposób, który uwypukla realia miejsca, gdzie rozgrywa się akcja powieści, a zasadniczym medium w tej przestrzeni staje się podróżujący autor eseju. Endō, czytając i interpretując Mauriakowską powieść, staje się (współ)uczestnikiem tak rozbudowanego procesu czytania, iż w efekcie uzyskujemy tekst dalece zrefigurowany, przekształcony, co do którego możemy powiedzieć, że Endō pisze własną wersję powieści Mauriaca, stając się również jej (współ)bohaterem. Jest to ważna cecha kontaktu Endō z tekstem, gdyż prowadzi ona do sytuacji, kiedy to istotny dla niego problem, znajdujący się w centrum powieści, zostaje powiązany i odniesiony bezpośrednio do jego osoby. Podmiotowość czytającego i piszącego Endō zostaje poddana różnorodnym formom modyfikacji.

W ten sposób zostaje przez niego uchwycona zależność na linii pisarzbohater-czytelnik, a relacje między nimi tworzą pełną napięć strukturę, we-

\footnotetext{
${ }^{24} \mathrm{Na}$ oddanie swojej sytuacji jako samotnego czytelnika powieści Mauriaca już od samego początku Endō używa słów kodoku bądź hitori (jako pojedynczy człowiek), odnosząc to do własnej samotności. Następnie za ich pomocą oddaje odczucie samotności, którego doświadcza w kolejnych etapach swej podróży (na przykład: yoru no kodoku no eki - stacja pogrążona w samotności nocy), wreszcie posługuje się słowem kodoku, gdy opisuje samotność bohaterów powieści, przede wszystkim Teresy (na przykład kodoku na onna - samotna kobieta; eien ni kodoku no ummei o ninau - Teresa obciążona losem odwiecznej samotności).
} 
wnątrz której zachodzące procesy prowadzą do szeregu przemieszczeń, roszad pomiędzy poszczególnymi jej elementami. Sądzę, że w ten sposób można przedstawić istotny dla Endō mechanizm "czytania i pisania" (w trakcie podróży), który pisarz inicjował, a następnie pozostawał pod wpływem jego oddziaływania. Każdy z elementów tego mechanizmu - pisarz, bohater, czytelnik - jest czymś odrębnym, a zarazem staje się poniekąd również pozostałymi w sieci wzajemnych interakcji.

Cały esej zdominowany jest przez kolejne, rozrastające się opisy natury - miejsca, z którym związana była fabuła powieści. Zastosowana przez Endō poetyka opisu pozwala wyobrazić sobie i odnieść bezpośrednio do jego osoby odczucie fizycznej obecności: opisuje drogę, którą przemierza, pisze o gorącu, wyczerpaniu, ogromnym pragnieniu i zupełnym wyobcowaniu. To kraina, gdzie próżno szukać drugiego człowieka.

Droga była wysuszona do białości i spalona promieniami słońca. Byłem desperacko spragniony. Domy wieśniaków, które mogłem zobaczyć czasami przez otwarte żywopłoty, wyglądały na martwe [...], nie mogłem zobaczyć ani jednego wieśniaka, z którym mógłbym porozmawiać. Niekiedy na mokradłach pojawiało się stado owiec z dzwonkami. Ale nie było ani jednego pastucha. W małych, opuszczonych winnicach ledwo mogłem znaleźć trochę wysuszonych winogron. Były zielone, twarde i gorzkie. Raz znalazłem w lesie studnię. Jednak wiedziałem, że pośród tych mokradeł starsi pastuszkowie poszukiwali śmierci w czarnych wodach takich studni (s. 152).

Jeszcze jeden ważny aspekt wejścia w „naturę” tego miejsca, który odnotowuje Endō, to odczucie ciszy ${ }^{25}$ - bodaj najbardziej dotkliwy wyraz obojętności świata: „wioska cicha jak trup”, „ale to, co Teresa wdychała [...], było ciszą jeszcze ciemniejszą, jeszcze bardziej przerażającą pustką, od której ta kobieta nie mogła uciec aż do końca nocy, aż do końca życia [...]. Wilgotne światło zmierzchu dawało wrażenie ciszy przypominającej śmierć" (s. 153 i 155).

Endō, przez kumulację symboliki, jej gęstość, nie wyróżnia żadnego pojęcia jako wiodącego. Natomiast kieruje naszą uwagę na stan zmieszania, niejasności, trwogi, jaką przychodzi mu odczuć w tym miejscu. Jest to miej-

${ }^{25}$ Endō zestawia ciszę zarówno z opisem otaczającej go natury, jak iz obrazem nocy i śmierci. Ciszę wyraża słowami shizukatta, shizukesa (cisza, spokój, bezruch, czyli to, co oznaczają angielskie tranquility czy stilness) oraz chinmoku (milczenie, brak słów). Podobne zestawienie pojawia się w innym eseju Endō zatytułowanym Aushubittu shūyōjo o mite („Widziałem obóz koncentracyjny w Auschwitz") z 1977 roku. Omawiam i analizuję opisy ciszy obecne w tym właśnie eseju w artykule A Place where Death Keeps Watch: Endō Shūsaku - a Japanese Christian Writer in Auschwitz, „The International Journal of the Humanities” 2012, nr 7, vol. 9, s. $197-210$. 
sce zdominowane przez nieuniknioność. „Mój los zawsze taki był” (s. 154) mówi Teresa. Zarówno ona, jak i każdy inny, kto znalazłby się w tym mikrokosmosie, staje się współuczestnikiem „nieczystości” tej krainy. Dotyka to również Endō, którego obecność w powieściowym Argelouse to bardzo rozbudowany opis tego, co męczące, odpychające i dalece determinujące: „nieustający hałas [...] podążał za mną, gonił mnie [...], muchy i inne owady w dużej ilości obłaziły mnie, jakby mnie przeklinały" (s. 152). Endō razem z Teresą zostają dotknięci przez determinującą zewnętrzność mauriakowskich Landes.

Opis odczuć wobec niemej, obojętnej i smutnej natury tego zakątka przeplatany jest rozmową, jaką podróżnik prowadzi z Teresą. Poszczególne sceny i słowa, czasami całe frazy z czytanej powieści Mauriaca, Endō przenosi bezpośrednio $\mathrm{w}$ "tu i teraz" scenerii miejsca, w którym się znalazł w swej podróży. Poprzez pytania, które zadaje Teresie, próbuje dociec jej intencji. Odpowiedzi, które słyszy, pochodzą od niego - układa w ten sposób swoją wersję myślenia Teresy, która tłumaczy swoje postępowanie: „impulsy mojego życia nie zawierają w sobie trucizny. Ale kiedy manifestują się jako czyny, przeradzają się w coś przerażającego" (s. 154). A zatem, konstatuje Endō: „Przyniosła swojemu mężowi truciznę, ponieważ chciała żyć" (s. 153). Wreszcie kieruje pytanie do samego siebie - „czy jest jakiś sens tej męczącej podróży?” (s. 154) - i z wyrzutem zwraca się do Teresy: „Dlaczego nie zniknęłaś w tych mokradłach? Obraz twojego życia jest dokładnie równy obrazowi tych bagien, bez śladów życia [...], z pozostałościami spalonych sosen" (s. 154-155).

Gdy Endō rozpoczynał tę podróż, pisał, iż „chciał usilnie sprawić by zniknął obraz Teresy, który był do tej pory [w nim]”. Jednak sierpień 1951 roku, który spędził w krainie Teresy, przyniósł coś odwrotnego. Kończąc esej, Endō wyznaje: „postać Teresy nie może zniknąć z moich oczu, nawet teraz. Pozostałem bez ruchu jak skamielina oparta o zmarłe drzewo, z jej osobą przed moimi oczyma na tle oślepiającego wieczornego słońca Landes" (s. 155).

\section{Podsumowanie}

Samotną podróż Endō Shūsaku szlakiem wyznaczonym losami Teresy Desqueyroux kontynuować będą również bohaterowie jego własnych powieści. W ostatniej, zatytułowanej Głęboka rzeka (1993 r.), główna bohaterka, Mitsuko, przemierza dokładnie tę samą trasę, co autor, odwie- 
dzając miejsca, które opisał Endō w swoim dzienniku i w eseju ponad czterdzieści lat wcześniej. Samotnej podróży Mitsuko towarzyszy powieść, którą nieustannie czyta i której fragmenty cytuje. W pewnym momencie sama mówi o sobie „Teresa”, a swojego japońskiego męża, którego decyduje się porzucić - niczym bohaterka Mauriaca - nazywa „Bernardem” (imieniem męża Teresy). Samotność Mitsuko nie jest jednak samotnością Endōczytelnika, Choć Endō uczynił swą literacką podróż punktem wyjścia do opowiedzenia losów własnej bohaterki, nadając jej tym samym wiele cech autobiograficznych, opisał jej samotność jako tę, która wynika raczej z poczucia nieprzynależności do schematu narzuconego przez społeczeństwo japońskie. Mitsuko świadomie decyduje się na samotność, bowiem widzi w niej możliwość potwierdzenia własnej wolności, odrębności i niezależności.

Podczas swojej samotnej pogoni za „cieniem Tersesy”, Mitsuko:

zrozumiała, że pociąg, którym w powieści Teresa jechała do lasu pogrążonego w ciemności, był wymysłem Mauriaca. Jeśli tak, to wobec tego Teresa nie przejeżdżała przez rzeczywisty las pogrążony w ciemności, lecz faktycznie podróżowała przez mroczną otchłań swego serca [...]. Uświadomiwszy to sobie, Mitsuko zrozumiała, że ona też [...] przyjechała do tej wioski po to, by odbyć podróż w poszukiwaniu mroków własnego serca [...]. Chociaż Mitsuko po raz pierwszy oglądała ten pejzaż w rejonie Landes, znała go świetnie z lektury Teresy Desqueyroux. [...] [Gdy] na dobre zapadła noc, którą autor nazwał „ciszą na krańcach ziemi”, leżąc w półmroku z oczami szeroko otwartymi [Mitsuko] patrzyła w sufit i pytała siebie: Czego ty chcesz tak naprawdę? Dlaczego przyjechataś tu sama?26

Podsumowując zainteresowania Endō twórczością Mauriaca i jego powieścią, warto również zaznaczyć, że nie zachowały się źródła które mogłyby potwierdzić by kiedykolwiek japoński pisarz spotkał się z Mauriakiem osobiście. Endō wielokrotnie przebywał we Francji (podróż roku 1951 nie była jego ostatnią wyprawą); o Mauriacu pisał niemal nieustannie w dzienniku, esejach, dla japońskich gazet; dokonał też własnego tłumaczenia Teresy Desqueyroux, do dziś uznawanego za jedno z najlepszych tłumaczeń Mauriaka na japoński.

Zdaje się, że samotna podróż w pogoni za "cieniem Teresy” trwała dla Endō aż do końca jego życia. W wydanym w roku 1985 zbiorze esejów i tekstów krytycznoliterackich pod tytułem Watashi ga aishita shōsetsu („Powieść, którą ukochałem"), potwierdził on, że jego podróż jeszcze się nie za-

${ }^{26}$ Endō Shūsaku, Głęboka rzeka, tłum. M. Melanowicz, Warszawa 1996, s. 72-74. 
kończyła. Takimi słowami pisarz podsumował cały zbiór ${ }^{27}$ : „Tak naprawdę moja książka powinna nosić tytuł Jak przeczytatem Teresę. Ale powiedzieć czytałem a przeczytałem to dwie różne rzeczy. Ja tak naprawdę nigdy nie skończyłem czytać tej powieści" 28.

\section{Kikō: Notes on Solitary Journey}

\section{Summary}

The article focuses on images of a solitary journey recorded in a literary form known as kikō (travel journals/diaries) that belongs to a long tradition of lifewriting narratives in Japan.

The point of departure is a short introduction on structural features of kiko as a genre whose purpose is to depict a solitary journey (undertaken by poets and writers) that traces literary motifs, fictional characters, or places described in literature. The introductory part highlights the continuation of the genre in the literary tradition of Japan from the Middle Ages to the present day, and indicates how kiko can be interpreted within the framework of Western diary studies, for example as defined by Philippe Lejeune.

The principal part of the paper analyses an essay written in 1952 by Endō Shūsaku Terēzu no kage o otte (Following the Shadow of Thérèse) as an example of a contemporary kikō. The essay is the testimony of Endō's solitary journey to the south-west corner of France in order to re-read and to capture the essence of a novel by François Mauriac, Thérèse Desqueyroux. This novel so significantly influenced Endō's oeuvres that at the end of his life the writer would call it "the novel I have loved".

${ }^{27}$ Zbiór ten poświęcony jest analizie powieści Mauriaca Teresa Desqueyrox, którą to analizę Endō podejmuje, odwołując się do rozmaitych nurtów filozoficznych czy teorii literackich. Czyta powieść między innymi poprzez wybrane zagadnienia socjologii Fromma, teorię archetypów Junga czy psychoanalizę Freuda.

${ }^{28}$ Endō Shūsaku, Watashi ga aishita shōsetsu, [w:] Endō Shūsaku Bungaku Zenshū, t. 14, Tokyo 2004, s. 123. 